\title{
GENERAL ANAESTHESIA AND TOTAL HIP REPLACEMENT*
}

\author{
K.W. TUhnBUlL, B.A.SC., M.D., F.R.C.P.(C) †, J.L. BEREZOWSKYJ, B.SC., M.D., C.M. †, \\ J.B. PoulsEN, M.D., F.R.C.S.(C)丰 AND L.S. Root $\dagger$
}

TOTAL HIP REPLACEMENT has become a frequent procedure since the initial work of Charnley, McKee, Watson, Ferrar and Ring in the early 1960s. The most popular technique, that of Müller, ${ }^{2}$ involves a socket prosthesis fixed in the acetabulum with acrylic bone cement. A femoral prosthesis is then fixed in the medullary cavity with the same acrylic cement. Peroperative complications associated with prosthesis implantation have ranged from transient hypotension, ${ }^{3}$ cardiac arrest, ${ }^{4}$ and embolic phenomena ${ }^{5,6,7}$ to significant decreases in arterial oxygen tension. ${ }^{8,9}$ This study is an attempt to review the clinical management of these patients with particular attention to their needs during operation. An attempt is also made to assess the significance of variations of the cardiovascular and pulmonary gas exchange which are associated with the use of acrylic bone cement. Alveolararterial oxygen gradients $\left(\mathrm{A}-\mathrm{aDO} \mathrm{O}_{2}\right)$, arterio-alveolar carbon dioxide gradients $\left(\mathrm{a}-\mathrm{ADCO}_{2}\right)$, and venous admixture $(\mathrm{Qs} / \mathrm{Qt})$ are used to assess these variations.

\section{Materials and Methods}

Forty-one patients were studied. The majority of these had osteoarthritis of the hip (s) and were moderately obese. The range of diseases included rheumatoid arthritis, avascular necrosis (hip), atherosclerotic cardiovascular disease (central and peripheral), chronic bronchitis and diabetes mellitis (Table I). The youngest patient was 23 years old (severe rheumatoid arthritis) and the oldest was 80 years old (osteoarthritis of both hips) with a mean age of $64.7 \pm 1.8$ years. There were 17 males and 24 females in this group. All patients were assessed in a systemic way (Table II). Particular attention was paid to anatomical, physiological and pharmacological evaluations; for example, all patients were receiving acetyl salicylic acid and some were on steroids.

All patients were seen preoperatively by the senior author (K.W.T.) and all were premedicated with a narcotic and belladonna. Induction and maintenance of anaesthesia were similar in all cases. Thiopentone and succinylcholine were employed for induction and relaxation for orotracheal intubation. Anaesthesia was maintained with nitrous oxide and oxygen $4 \mathrm{~L} / 2 \mathrm{~L}$ with the addition of halothane 0.75 per cent to 1.0 per cent. D-tubocurarine 27 to $30 \mathrm{mg}$ was employed for relaxation during operation, and all patients were ventilated with a Bird Mark VIII ventilator at a tidal volume of 8 to $9 \mathrm{cc} / \mathrm{kg}$.

'Presented in part at Canadian Anaesthetists' Society Annual Meeting, St. John's, Nfld, June 1974.

†Department of Anaesthesiology, Vancouver Ceneral Hospital and Faculty of Medicine, University of British Columbia.

$\$ 236$ Greenstone Drive, Kamloops, B.C. 
TURNBULL, et al.: GENERAL ANAESTHESIA AND TOTAL HIP REPLACEMENT

TABLE I

Clinical Diagnoses of 41 Patients Studied (Preoperative)

\begin{tabular}{lclc}
\hline Orthopedic Diagnosis & Percentage & Medical Diagnosis & Percentage \\
\hline Osteoarthritis & 75 & Obesity & 20 \\
Avascular Necrosis & 10 & Atherosclerotic Heart & 17 \\
Rheumatoid Arthritis & 5 & Disease & 8 \\
Coxarthrosis & 2.5 & Hypertension & 5 \\
Ankylosing Spondylitis & 2.5 & Chronic Bronchitis & 2.5 \\
Nonunion of Fracture & 2.5 & Diabetes Mellitus & 2.5 \\
Miscellaneous & 2.5 & Asthma & \\
\hline
\end{tabular}

TABLE II

Systems Evaluation (Anaesthetic and Operative)

1. Anatomical
(a) airway
(b) contractures
(c) wasting
(d) peripheral vessels (veins)
(e) other

2. Physiological
(a) obesity
(b) cardiovascular disease (age or disease related)
(c) dehydration (fluid and electrolytes)
(d) other e.g. anaemia, hypothermia

3. Pharmacological
(a) steroids
(b) ASA, phenylbutazone
(c) antihypertensive medications
(d) digitalis
(e) diuretics
(f) others, e.g. gold

4. Special
(a) posture e.g. nerves, skin, joints
(b) infection
(c) multiple anaesthetics
(d) liver and methacrylate

The patients were all operated upon in the right or left lateral position, while in thirteen cases a $5^{\circ}$ head down tilt was also applied.

Large-bore intravenous lines were employed and moderate rehydration was achieved using a minimum of $500 \mathrm{cc}$ of 5 per cent glucose in lactated Ringer's solution and two units of blood.

Arrangements for monitoring during operation included a sphygmomanometer for blood pressure measurements (Riva-Rocci), a precordial Doppler flow probe over the tricuspid valve, electrocardioscope, Wright's respirometer, continuous end-tidal carbon dioxide $\left(\mathrm{ETCO}_{2}\right)$ recording (Beckman LB1) and continuous end-tidal oxygen $\left(\mathrm{F}_{\mathrm{ET}} \mathrm{O}_{2}\right)$ measurement (Servomex Type OA 150 Oxygen Analyzer). Intra-arterial catheters and central venous catheters (in SVC or RA) were used for sampling and direct pressure recording (General Electric Patient Monitor) in 16 patients. Catheter positions were checked by chest roentgenograms. Direct arterial carbon dioxide tensions $\left(\mathrm{PaCO}_{2}\right)$ were measured in five patients (General Electric Blood Gas Patient Monitor). 
Blood samples were taken in heparinized glass syringes prior to insertion, at insertion and at 1.5, 3.0, 5.0 and 30 minutes after insertion of the femoral prosthesis. They were iced and analyzed within 20 minutes on a Radiometer $\mathrm{pH} /$ Blood Gas monitor Unit at $37^{\circ} \mathrm{C}$. The values were corrected for patient temperature changes. Similar sampling was done after insertion of acetabular prostheses.

End-tidal gas samples were acquired through a constant length of plastic tubing inserted $6 \mathrm{~cm}$ down the tracheal tube lumen. The peak end-tidal oxygen and carbon dioxide concentrations of the respiratory cycle corresponding to the blood sampling periods were assumed to equal the alveolar oxygen and carbon dioxide concentrations. ${ }^{10}$ These values were used to calculate $\mathrm{A}-\mathrm{aDO}_{2}$ and a- $\mathrm{ADCO}_{2}$ after allowance was made for ambient barometric pressure, water vapour and inhaled nitrous oxide. ${ }^{11}$ Respiratory exchange ratio $(R)$ was calculated using the measured end-tidal gases.

Venous admixture ( $\mathrm{Q}_{\mathrm{s}} / \mathrm{Qt}^{\mathrm{t}}$ ) was calculated using the following standard formulae $\left.{ }^{12}: Q_{s} / Q=\left(\mathrm{Cc}^{\prime} \mathrm{O}_{2}-\mathrm{CaO}_{2}\right) / \mathrm{Cc}^{\prime} \mathrm{O}_{2}-\mathrm{C}_{\mathrm{V}_{2}}\right)$ where $\mathrm{Co}_{2}=(1.39 \times$ percent saturation $\times \mathrm{Hb} \times \mathrm{PO}_{2} \times 0.0031$ ) and $\mathrm{c}^{\prime}$, a and $\bar{v}$ represent end-capillary (assumed equal to alveolar or end-tidal), arterial and mixed venous (SVC or RA) values, respectively. Percentage oxygen saturation was derived from measured $\mathrm{PO}_{2}$ and $\mathrm{pH}$ values using Severinghaus and Astrup nomograms.

\section{Operative Technique}

The surgical technique was that of $\mathrm{Müller}^{2}$ with some minor modifications. Preoperative antibiotics, careful gowning, double gloves, protective hoods, masks, boots and restricted operating room traffic were used in most cases to minimize the risk of infection. The methylmethacrylate cement was vigorously mixed for four to five minutes and then placed in the acetabulum or in the shaft of the femur, which was vented by plastic tubing. The tubes were removed before the femoral prosthesis was tapped into place. Cement weights were recorded in the 16 cases in whom blood gases were monitored. Optimal relaxation was assured with previous "top-up" doses (6 mg) of D-tubocurarine in many cases.

Blood replacement was initiated as soon as the skin incision was made in all but one case. Blood losses were determined by weighing sponges and recording suction losses. Losses in the recovery room from wound drains (Hemovac ${ }^{\circledR}$ ) were included.

\section{Results}

Operative time averaged $2.10 \pm 0.05$ hours. The anaesthetic time of $2.60 \pm 0.07$ hours commenced with the insertion of the first intravenous line and ended with the patient's arrival in the recovery room. Mean operative and recovery room blood loss was $850 \pm 59 \mathrm{ml}$ with blood replacement being $1050 \pm 45 \mathrm{ml}$ (Table III). All patients but one were free of arrhythmias, hypotension or changes in the heart sounds (Doppler) or rhythm during operation. This one patient did not have blood transfusion started until the femoral cement was inserted. The amount of methylmethacrylate cement used in the acetabulum $(28.9 \pm 2.0 \mathrm{gm})$ almost equalled that used for the femoral shaft $(28.1 \pm 2.5 \mathrm{gm})$ (Table IV). 
TABLE III

Clinical and Operative Patient Data

$(n=41$, mean \pm s.d.)

\begin{tabular}{|c|c|c|c|c|c|}
\hline $\begin{array}{l}\text { Age } \\
(\mathrm{yr})\end{array}$ & $\underset{(\mathrm{kg})}{\text { Weight }}$ & $\begin{array}{c}\text { Anaesthetic } \\
\text { Time } \\
\text { (hr) }\end{array}$ & $\begin{array}{c}\text { Operative } \\
\text { Time } \\
\text { (hr) }\end{array}$ & $\begin{array}{c}\text { Blood loss } \\
\text { (or + par) } \\
\text { (ml) }\end{array}$ & $\begin{array}{c}\text { Blood } \\
\text { replacement } \\
\text { (or + par) } \\
(\mathrm{ml})\end{array}$ \\
\hline $64.7 \pm 1.8$ & $66.8 \pm 1.7$ & $2.60 \pm 0.07$ & $2.10 \pm 0.05$ & $850 \pm 59$ & $1050 \pm 45$ \\
\hline
\end{tabular}

TABLE IV

Methylmethacrylate Cement

\begin{tabular}{llll}
\hline Composition & Formula/Reaction & \multicolumn{2}{c}{$\begin{array}{c}\text { Amounts used } \\
\text { (n=16, mean } \pm \text { s.d.) }\end{array}$} \\
\hline $\begin{array}{l}\text { Liquid + Powder } \\
\text { (monomer) (polymer) }\end{array}$ & $\begin{array}{l}\text { Acetabulum } \\
\text { Femoral Shaft }\end{array}$ \\
$\begin{array}{l}\mathrm{CH}_{2}=\mathrm{C}-\mathrm{C}-\mathrm{O}-\mathrm{CH}_{3} \\
\text { polymerization of liquid } \\
\text { monomer binding previously } \\
\text { polymerized powder in an } \\
\text { exothermic reaction }\end{array}$ & $28.9 \pm 2.0 \mathrm{gms}$ & $28.1 \pm 2.5 \mathrm{gms}$ \\
\hline
\end{tabular}

Insertion of acrylic cement was followed by highly significant $(P=0.01)$ drops in arterial oxygen tension $\left(\mathrm{PaO}_{2}\right)$ following acetabular replacement at $1.5,3.0$, 5.0 minutes after insertion and in femoral head replacement at 1.5 and 3.0 minutes after insertion (Tables V and VII, Figure 1). The mean decreases were $9.0 \pm 5.6 \mathrm{~mm} \mathrm{Hg}$ (acetabular) and $17.5 \pm 5.5 \mathrm{~mm} \mathrm{Hg}$ (femoral). Highly significant $(\mathrm{P}=0.01)$ increases in $\mathrm{A}-\mathrm{aDO}_{2}$ paralleled these changes in $\mathrm{PaO}_{2}$. Significant decreases in a-ADCO $2(\mathrm{P}=0.05)$ occurred at acetabular insertion and lasted for three minutes (Table V). Highly significant increases in a-ADCO, $(\mathrm{P}=0.01)$ occurred following femoral prosthesis insertion and lasted for three minutes (Table VII, Figure 2). Mean expiratory exchange ratios (R) varied from 0.962 to 0.981 . Venous admixture $(\mathrm{Q} / \mathrm{Qt}$ ) was highly significantly increased $(\mathrm{P}=0.01)$ to 16.0 per cent, 1.5 minutes after prosthesis insertion in the femur (Table VI) and also at three minutes after insertion of the prosthesis in the femur (to 16.0 per cent) and the acetabulum (to 12.0 per cent). In both cases Qs/Qt returned towards normal values (9.0 \pm 3.2 per cent in this study) within five minutes of insertion of the cement and prosthesis, while the $\mathrm{A}-\mathrm{aDO} \mathrm{O}_{2}$ and a-ADCO${ }_{2}$ changes persisted for at least five minutes.

\section{Discussion}

Comparison of the acid-base measurements (Tables V-VIII) confirm the stability of ventilation (shown by $\mathrm{PaCO}_{2}$ ) and metabolic status (shown by $\mathrm{pH}$ and $\mathrm{HCO}_{3}^{-}$) in the study group. Although relatively high central venous oxygen tensions suggest adequate peripheral tissue perfusion, these values may be slightly higher than those of true mixed venous samples because of the location of the 
TURNBULL, et al.: GENERAL ANAESTHESIA AND TOTAL HIP REPLACEMENT

TABLE VI

Central Venous Data and Calculated Venous Admixture ( $\dot{Q} s / \dot{Q} t)$ After ACETABULAR REPLACEMENT

$(\mathrm{n}=16$, all values means \pm s.d.)

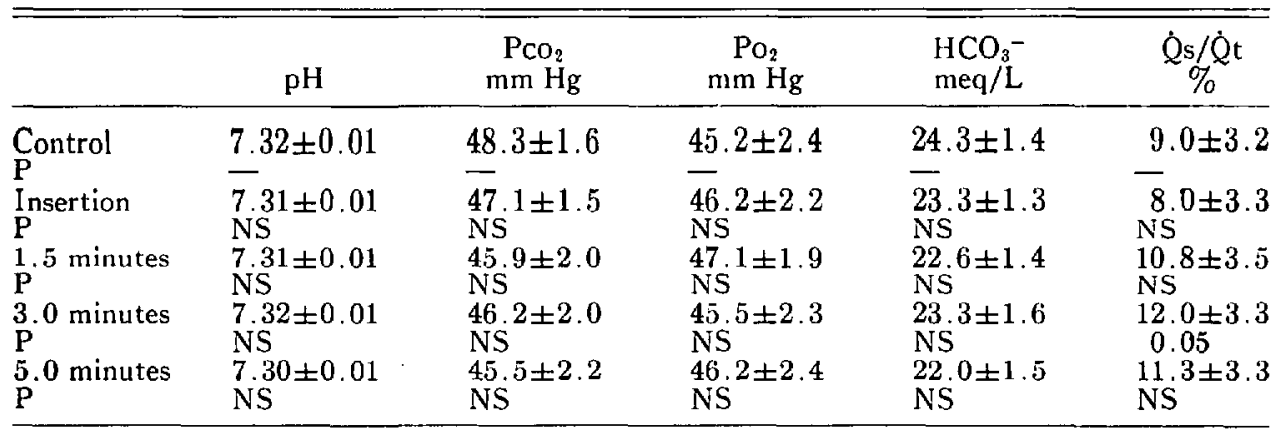

catheter tip. ${ }^{13,14}$ The accuracy of central venous samples as a measure of pooled venous blood is useful and predictable in patients who are not in shock. ${ }^{14}$

Control venous admixture $\left(Q_{s} / Q t\right)$ values of $9.0 \pm 3.2$ per cent are quite acceptable, when compared with other studies. ${ }^{15,16}$ The transience of change in $\mathrm{Qs} / \mathrm{Qt}$ and $\mathrm{PaO}_{2}$ associated with acrylic cement insertion strongly favours changes in ventilation-perfusion, pulmonary arterio-venous shunts and/or cardiac output rather than any form of micro- or macro-emboli, atelectasis or platelet aggregation. The lack of changes in heart sounds, heart rhythm, blood pressure and central venous oxygen tension eliminates changes in cardiac output and particulate or gas emboli. The increases in $\mathrm{A}-\mathrm{aDO}_{2}, \mathrm{a}-\mathrm{ADCO}_{2}$, and $\mathrm{Qs} / \mathrm{Qt}$ following insertion of femoral prostheses suggest that increased pulmonary arteriovenous shunting and ventilation-perfusion defects occur ${ }^{12}$ (Table IX). The decrease in a-ADCO${ }_{2}$ occurring with acetabular replacement may reflect some beneficial change in ventilation-perfusion matching secondary to tidal volume redistribution after bronchiolar constriction from the first exposure of the patients to acrylic cement. ${ }^{9}$ Further acrylic cement in the systemic circulation may reverse this effect.

The decrease in $\mathrm{PaO}_{2}(17.5 \pm 5.5 \mathrm{~mm} \mathrm{Hg})$ is smaller in this group than in other reported series. ${ }^{8.9}$ This may reflect the agressive fluid administration used in this series. Avoidance of hypotension and keeping at least one unit of blood $(450 \mathrm{cc}$ ) ahead of losses prior to cement insertion probably helped to minimize the vasodilatory and shunting effects of the acrylic bone cement.

Fumes released as the cement is polymerizing may be harmful to the liver of both patient and operating room personnel. Initial studies in dogs suggest mild liver dysfunction can occur if free monomer reaches the liver. ${ }^{17}$ This possibility should be considered when the anaesthetic agent is chosen.

\section{CONCLUSION}

The patient for total hip replacement is a challenge to all anaesthetists. Consideration of the patient's airway, age, weight and cardiovascular status are extremely important. Careful anaesthetic technique augmented by adequate hydration and blood transfusion prior to insertion of the cement is important in 


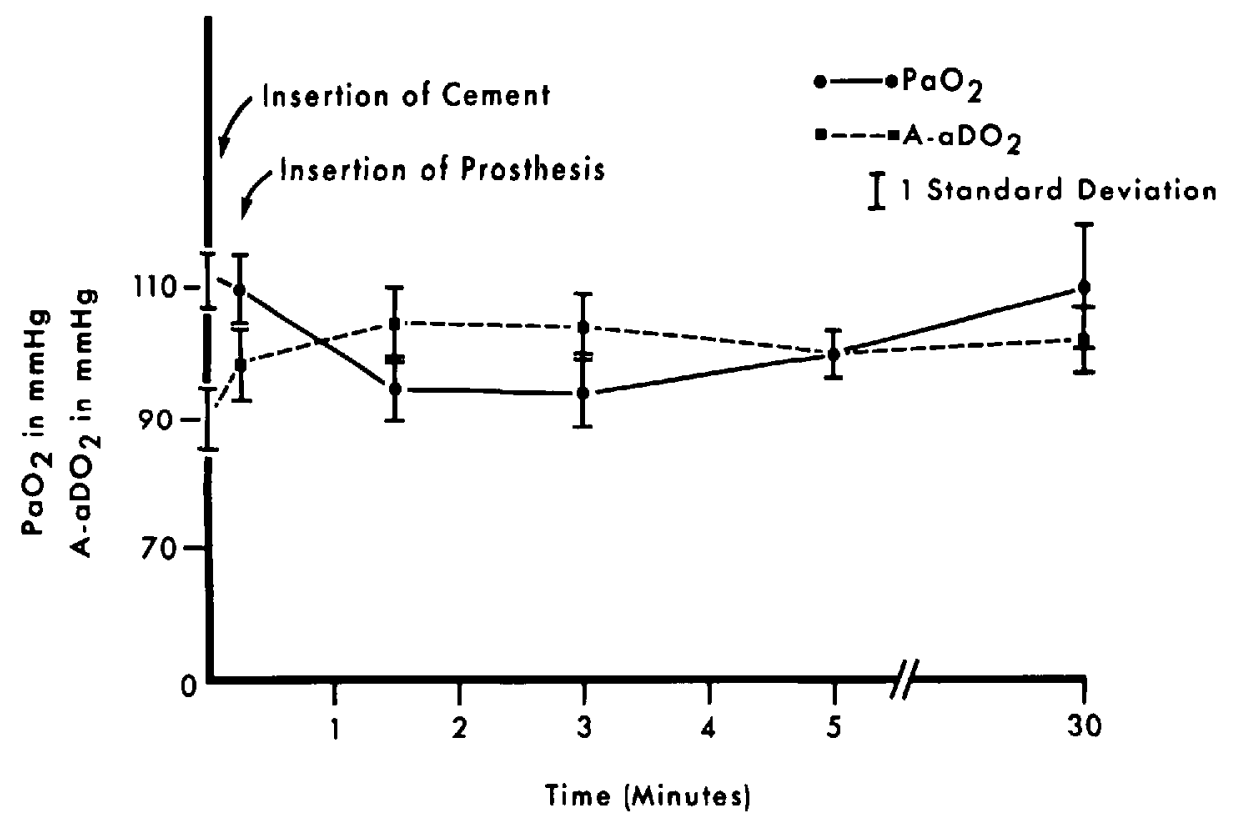

Figure 1. Changes in arterial oxygen tension $\left(\mathrm{PaO}_{2}\right)$ and alveolar-arterial oxygen gradient $\left(\mathrm{A}-\mathrm{aDO} \mathrm{O}_{2}\right)$ after insertion of the femoral prosthesis.

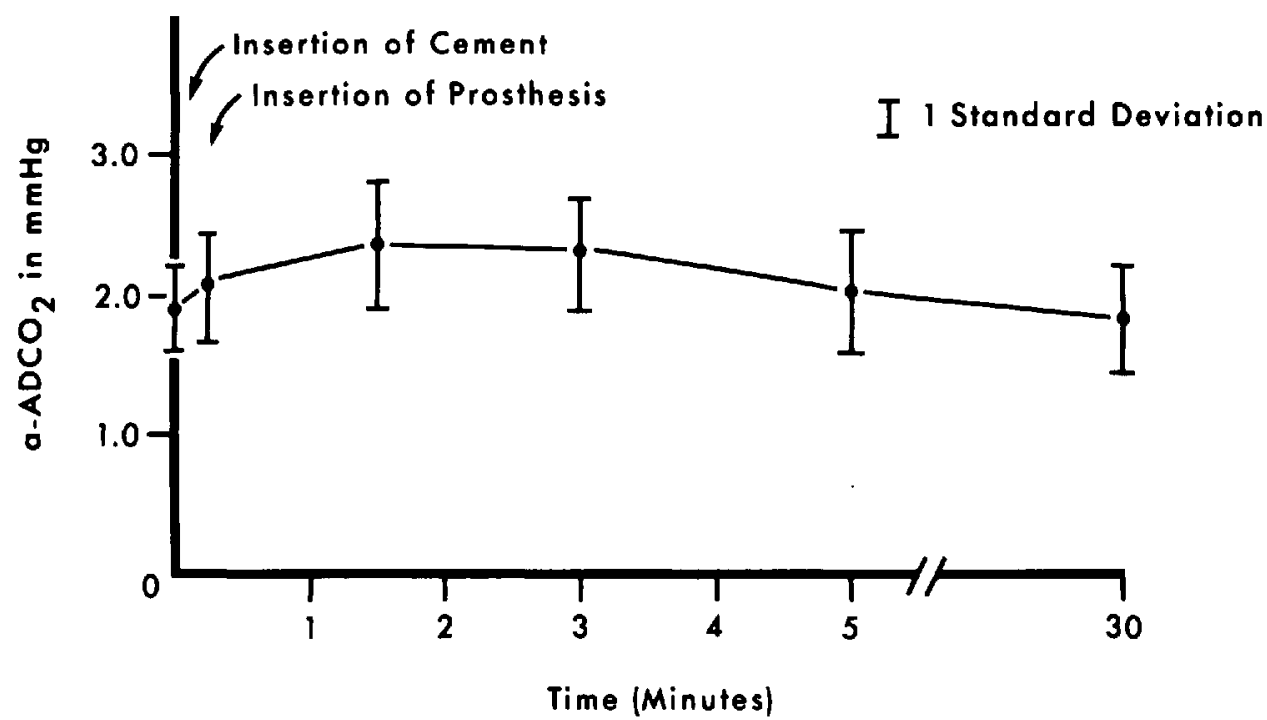

Figure 2. Changes in arterial-alveolar carbon dioxide gradient (a-ADCO ${ }_{2}$ ) after insertion of the femoral prosthesis.

the prevention of hypovolaemia in these patients. Cement insertion will precipitate increases in venous admixture and mean concomitant decreases in arterial oxygen tension of at least $17.5 \mathrm{~mm} \mathrm{Hg}$ with a vented femur. Inspired oxygen tension should be increased by at least 20 per cent (i.e. to 50 per cent) prior to cement insertion to avoid hypoxaemia in these patients. Anaesthetic agents with 
TABLE VIII

Central Venous Data and Calculated Venous Admixture (Q́s/Qt) AfTer Femoral Head Replacement $(\mathrm{n}=16$, all values : means \pm s.d.)

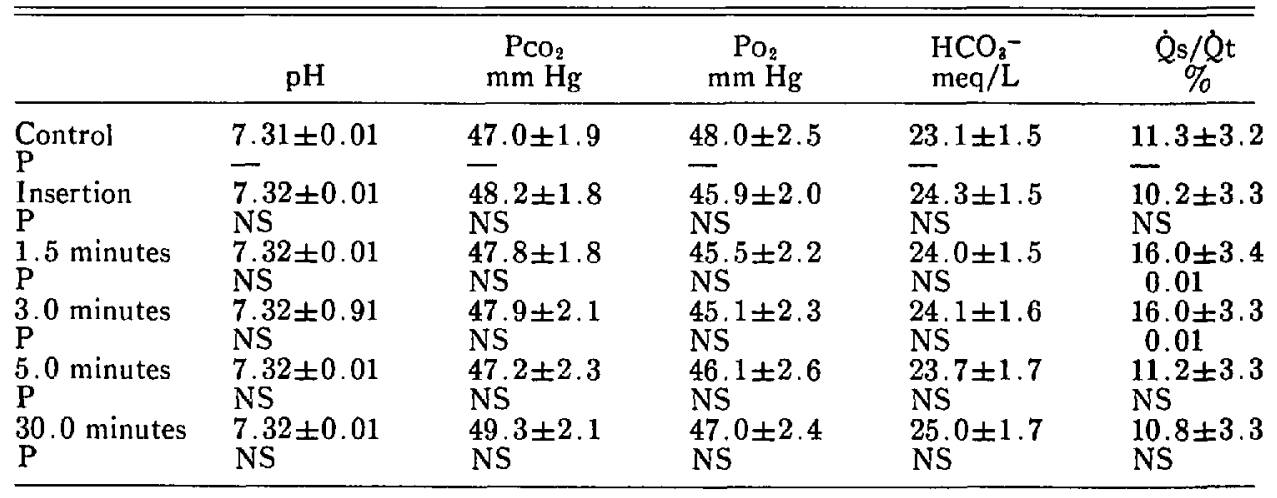

TABLE IX

Summary of Venous Admixture Data

1. Acetabular Replacement

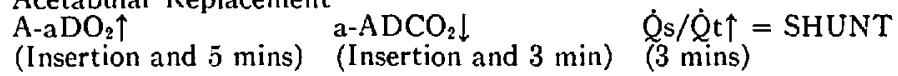

2. Femoral Head Replacement

\begin{tabular}{|c|c|c|}
\hline $\begin{array}{l}\mathrm{AaDO}_{2} \uparrow \\
\text { (Insertion to } 5 \text { mins) }\end{array}$ & $\begin{array}{l}\text { a-ADCO } \\
\text { (Insertion and } 3 \mathrm{~min} \text { ) }\end{array}$ & $\begin{array}{l}\dot{\mathrm{Qs}} / \dot{\mathrm{Q}} \mathrm{t} \uparrow=\mathrm{SHUNT}+\dot{\mathrm{V}} / \dot{Q} \\
(1.5 \text { and } 3 \mathrm{~min})\end{array}$ \\
\hline
\end{tabular}

minimal effects on liver function are to be preferred because it is possible that fumes from the polymerization of the cement may be harmful.

\section{'Summary}

Decreases in arterial oxygen tension $\left(\mathrm{PaO}_{2}\right)$ and increased venous admixture ( $\mathrm{Qs} / \mathrm{Qt}$ ) occur with acrylic cement insertion. Mean decreases in $\mathrm{PaO}_{2}$ of 17.5 $\mathrm{mm} \mathrm{Hg}$ occurred in this study of 41 patients. Qs/Qt increased by 7 per cent to 16.0 per cent during general anaesthesia with $\mathrm{N}_{2} \mathrm{O}_{0} \mathrm{O}_{2}$ - Halothane (4L:2L:1\%) and d-tubocurarine. Assessment of pulmonary gas exchange using $\mathrm{PaO}_{2}, \mathrm{~A}-\mathrm{aDO}$, a-ADCO.. and acid-base studies using arterial and central venous blood samples in 16 patients suggest that both ventilation-perfusion mismatch and pulmonary arterio-venous shunts occur transiently after acrylic bone cement is used. Stable central venous oxygen tensions and normal heart sounds (Doppler), heart rhythm and stable blood pressure suggest that cardiac output changes, if any, are minimal.

Patients for total hip replacement are most commonly females, obese, in their 60 s and often have airway or cardiovascular disease. General anaesthesia must be conducted with particular attention to prevention of hypovolaemia by adequate rehydration and aggressive blood transfusions, prior to cement insertion into the vented femoral shaft. Inspired oxygen tension should be increased to 50 per cent prior to cement insertion. The oxygen tension may be returned to the pre-inser- 
tion value 15 minutes after cement insertion. Fumes from the polymerizing acrylic cement may cause some liver dysfunction but insufficient data is available to confirm this.

\section{RÉSUMÉ}

Des baisses de la saturation artérielle en oxygène $\left(\mathrm{PaO}_{2}\right)$ et une élévation du shunt veineux (Qs/Qt) accompagnent l'application de l'acrylique. Une baisse moyenne de $\mathrm{PaO}_{2}$ de $17.5 \mathrm{~mm} \mathrm{Hg}$ fut observée dans cette étude de 41 patients. Pendant l'anesthésie générale au $\mathrm{N}_{2} \mathrm{O} \cdot \mathrm{O}_{2}$ - halothane (4L:2L:1\%) et d'tubocurarine, le $\mathrm{Qs} / \mathrm{Qt}$ s'est élevé de 7 pour cent à 16 pour cent. L'évaluation des échanges gazeux pulmonaires, d'après l'étude des $\mathrm{PaO}_{2}, \mathrm{AaDO}_{2}$ et de l'équilibre acido-basique avec échantillons artériels et veineux mixtes chez 16 patients démontre l'existence transitoire de déséquilibre entre la ventilation et la perfusion et de shunt artério-veineux, secondaire à l'emploi d'acrylique. La stabilité de la pression partielle d'oxygène du sang veineux mixte, les bruits et le rythme cardiaque normaux (Doppler) et une pression artérielle stable attestent du peu de changement dans le débit carriaque.

Les patients sujets à une prothèse totale de la hanche sont le plus souvent des femmes obèses, sexagénaires et porteuses de maladies pulmonaires ou cardiovasculaires. L'anesthésie générale doit être administrée avec attention spéciale à la prévention de l'hypovolémie: remplacement liquidien adéquat et attitude agressive vis-à-vis les transfusions sanguines avant l'application de l'acrylique à l'intérieur du canal béant de l'os fémoral. La pression partielle de l'oxygène du mélange inspiré devrait être augmentée à 50 pour cent avant l'application de l'acrylique; on pourra revenir à la concentration première, quinze minutes après l'application. Les vapeurs émises par la polymérisation de l'acrylique pourraient provoquer une dysfonction hépatique, mais les données sont trop peu nombreuses pour confirmer ce fait.

\section{Conclusion}

Les candidats à prothèse totale de la hanche présentent un défi particulier à l'anesthésiste.

Au départ, il faut tenir compte des facteurs de risques, tels que l'âge, le poids, l'état cardio-vasculaire et pulmonaire. Une technique anesthésique minutieuse avec hydratation adéquate et remplacement anticipé des pertes sanguines avant l'insertion du ciment sont très importants pour prévenir un hypovolémie. L'application de l'acrylique s'accompagne d'une augmentation du shunt veineux pulmonaire avec baisse de la $\mathrm{PaO}_{2}$. La FiO $\mathrm{FiO}_{2}$ du mélange inspiré devrait être augmentée d'au moins 20 pour cent $\left(\mathrm{FiO}_{2} 0.5\right)$ avant l'installation du ciment. Les agents présentant les effets les moins marqués sur la fonction hépatique seront les agents, de choix, considérant la possibilité de toxicité des vapeurs produites lors de la polymérisation de l'acrylique. 


\section{ACKNOWLEDGMENTS}

The authors are grateful to all the members of the Department of Orthopaedics of the Vancouver General Hospital for allowing access to their patients. Particular thanks are directed to Drs. R.W. McGraw and F.P. Patterson.

\section{REFERENCES}

1. Coventry, M.B., Beckenbaugh, R.D., Nolan, D.R., \& Ilstrup, D.M. 2,012 total hip Arthroplastics: a study of postoperative course and early complications. J. of Bone and Joint Surg, 56-A: 273 (1974).

2. MüLlen, M.E. Total hip protheses, clinical orthopaedics and related research, 72: 46 (1970).

3. Phillips, H., Cole, P.V., \& Lettin, A.W.F. Cardiovascular effects of implanted acrylic bone cement. Brit. Med. J. 3: 460 (1971).

4. Powell, J.N., McGrath, P.J., Lahiki, S.K., \& Hill, P. Cardiac arrest associated with bone cement. Brit. Med. J. 3: 326 (1970).

5. Herndon, H.H., Bechtol, C.C., \& Crickenbenger, D.P. Fat embolism during total hip replacement: a prospective study. Presented at Orthopedic Research Society, Dallas, Texas, January 15-17, 1974 (in press).

6. Kallos, T., Ems, J.E., Gord, M.I., Gollan, F., Davis, J.H., \& Sarmiento, A. Pulmonary embolization of femoral intramedullary contents during fixation of prosthesis with bone cement. Presented at Orthopedic Research Society, Dallas, Texas, January 15-17, 1974 (in press).

7. Ncai, S.H., Stinchfield, F.E., \& Thiner, L. Air embolism during total hip arthroplastics. Anesthesiology 40: 405 (1974).

8. Park, W., Balingit, P., Kenmore, P.I., \& MacNamara, T.E. Changes in arterial oxygen tension during total hip replacement. Anesthesiology 39: 642 (1973).

9. Modic, J., Olerud, S., \& Malmberg, P. Sudden pulmonary dysfunction in prosthetic hip replacement surgery. Acta Anaesth. Scand. 17:276 (1973).

10. RahN, H. A concept of mean alveolar air and the ventilation-blood flow relationship during pulmonary gas exchange. Am. J. Physiol. 158: 21 (1949).

11. Severinghaus, J.W. Methods of measurement of blood and gas carbon dioxide during anesthesia. Anesthesiology 21: 717 (1960).

12. NunN, J.F. Applied respiratory physiology. London, Butterworths p. 244 (1969).

13. Lee, J., Wright, F., Babrer, R., \& Stanley, L. Central venous oxygen saturation in shack: a study in man. Anesthesiology 36: 472 (1972).

14. Theye, R.A. \& Tuony, G.F. The value of venous oxygen levels during general anesthesia. Anesthesiology 26: 40 (1965).

15. Nunn, J.F., Bergman, N.A., \& Colemian, A.J. Factors influencing the arterial oxygen tension during anaesthesia with artificial ventilation. Brit. J. Anaesth. 37: 898 (1965).

16. Sykes, M.K., Young, W.E., \& Robisson, B.E. Oxygenation during anaesthesia with controlled ventilation. Brit. J. Anaesth. 37: 314 (1965)

17. McLaughlin, R.E., Difazio, C.A., Hakala, M., Abbott, B., MacPhail, J.A., Mack, W.P., \& SWEET, D.E. Blood clearance and acute pulmonary toxicity of methylmethacrylate in dogs after simulated arthroplasty and intravenous injection. J. of Bone and Joint Surg. 55-A: 1621 (1973). 